\title{
PCTOC, 40 years on: an anniversary editorial
}

\section{Sergio Ochatt ${ }^{1}$ (1)}

Accepted: 21 April 2021 / Published online: 29 April 2021

(c) The Author(s), under exclusive licence to Springer Nature B.V. 2021

Since the first issue of our journal appeared, in January 1981, about 5600 articles were published over these 40 years we are celebrating, and it is exceedingly difficult to highlight just a few of them. It is however with great joy that I embraced this task and do hope that our readers over this long and enriching period will find my choice pertinent.

In the very first article published in PCTOC, Thom et al. (1981) studied the growth traits and nutrient changes in both the medium and the cells of batch-grown sugarcane cultures. Although not cited massively, this was a foundation paper for many subsequent studies on the fate of nutrients in the medium and their concomitant accumulation in cultured cells, whilst also showing that a decrease of cytoplasmic space in favour of vacuolar space could be suitable indicators of the transition from the multiplication to the stationary phase in suspension cultured cells, while cell volume remained mostly unchanged during the growth cycle. They observed that amino acids, phosphate, potassium and organic (rather than inorganic) nitrogen were preferentially taken up from the medium.

The most highly cited article in these 40 years has been the study of Huetteman and Preece (1993) on the cytokinins properties of thidiazuron (TDZ) for tissue culture of woody plants, which has been cited 724 times so far. Low TDZ facilitated the micropropagation of many recalcitrant woody species. However, higher TDZ levels may stimulate callus formation as well as the production of adventitious shoots and somatic embryos, but also induce the formation of fasciated shoots and interfere with shoot elongation (often needed to root in vitro shoots of woody crops), requiring an additional shoot elongation step with less TDZ or an alternative, weaker cytokinin.

The second most cited article (with 434 citations) was the comprehensive review on the transition of somatic plant

Sergio Ochatt

sergio.ochatt@inrae.fr

1 UMR 1347 Agroécologie, AgroSup/INRAE/uBFC, 17 Rue Sully, 21000 Dijon, France cells to an embryogenic state by Fehér et al. (2003), where they guided the readers through the link between somatic embryogenesis and the molecular and cellular bases of developmental plasticity in plants. They provided novel mechanistic insight on this paramount in vitro process, and discussed the role of stress, endogenous growth regulators and the remodelling of chromatin in the cell reorganisation required for developmental plasticity.

Jacyn Baker and Mock (1994) developed an improved spectrophotometric procedure to reliably and rapidly monitor cell death using Evans blue in leaf discs and cell suspensions, that they used to compare plant/bacteria interaction of soybean/Pseudomonas syringae pv. glycinea or tobacco/P . syringae pv. syringae. This work was cited 348 times.

In an authoritative review that has attracted 293 citations, von Arnold et al. (2002) detailed and critically discussed the developmental pathways of somatic embryogenesis. They outlined the morphological and molecular determinism of the critical developmental stages occurring sequentially from the differentiation of proembryogenic masses through to the conversion of the somatic embryos into viable plantlets.

The article which was accessed most often-nearly 7000 times - and cited 288 times is the review by Murthy et al. (2014) on the strategies and approaches to produce secondary metabolites from in vitro cultures. There, the authors browsed and discussed the parameters controlling the growth and multiplication of cells and organs in vitro leading to increased biomass accumulation and optimal production of secondary metabolites.

The report by Bett et al. (2017) on the recovery of transgenic cowpeas (Vigna unguiculata L. Walp) that were protected against the Maruca pod borer (Maruca vitrata) by over-expressing Bacillus thuringiensis Vip3Ba protein was the second most popular article of our journal online being accessed nearly 4800 times, with 21 citations so far and reaching an Altmetric score of 57. The coding sequences of several vip3 genes from Bacillus thuringiensis were cloned and overexpressed in Escherichia coli to produce the Vip3 protein which, integrated in the diet of Maruca larvae strongly inhibited their growth. In turn, cowpea plants 
transformed with Vip3Bal gene were fully protected from this pest.

The best Altmetric score in these years was attained by the very recent article of O'Brien et al. (2021) who reported for the first time on a successful method for the cryopreservation of mature shoot tips of two avocado (Persea americana Mill.) rootstocks. With an Altmetric score of 310, this article is in the 99th percentile (ranked 2358th) of the 307,526 tracked articles of a similar age in all journals. Shoots were subjected to two different optimised pre-treatments $\left(0.3 \mathrm{M}\right.$ sucrose or $10{ }^{\circ} \mathrm{C}$ incubation) for two weeks prior to shoot tip dissection and five durations of treatment with either of two plant vitrification solutions were tested before evaluation of survival and regrowth after 2 and 8 weeks following such vitrification and either with or without exposure to liquid nitrogen, whereby optimal exposure time for each cultivar varied with the cryoprotectant used.

The second highest Altmetric score was for the article by Gupta and Van Eck (2016) reporting how modifying the plant regeneration medium accelerated the recovery of tomato cultivar M82 stable transgenic lines. This article was accessed 1549 times, attracted 13 citations and, with an Altmetric score of 88, it is in the 97th percentile (ranked 7601 st) of the 267,100 tracked articles of a similar age in all journals. The authors improved responses and decreased the time for recovery of transgenic lines from cotyledon explants by 6 weeks compared to their standard protocol (where only zeatin is included in the medium) by adding IAA (indole3 -acetic acid) to the regeneration medium and, later, also to the rooting medium without any negative effects on plants.

Finally, the third highest Altmetric score to date was achieved by the article by Nakano et al. (2021), with a score of 66, which places it in the 96th percentile (ranked 8558th) of 234,819 tracked articles of a similar age in all journals. The authors reported the simultaneous production of triploid and hexaploid plants with a colchicine treatment of endosperm-derived callus of diploid Haemanthus albiflos, a highly ornamental value member of the Amaryllidaceae. Such calluses were induced on Murashige and Skoog (MS) medium with picloram and 6-benzylaminopurine (BAP). Somatic embryos and adventitious shoots regenerated on hormone-free $1 / 2 \mathrm{MS}$ medium, they developed on a medium with 1-naphthaleneacetic acid (NAA) and BAP, and converted into full plants on hormone-free 1/2MS medium. Flow cytometry assessments showed that the regenerants were diploid, triploid, and tetraploid. However, when the endosperm-derived calluses were treated with colchicine four hexaploid plants were regenerated using the same media sequence, as also confirmed by chromosome counts.

How can one be fair and yet retain only the most significant papers from such a huge number and long period during which research in plant biotechnology has witnessed so many revolutionary advances? The honest answer is that simply we cannot. I have therefore decided to follow the most objective method I could think of, which is that of including in my selection the very first article published in the journal, then randomly selecting amongst the most highly cited articles over this time span and finally adding some of the most landmark and ground-breaking results recently published in PCTOC, as witnessed by their Altmetric scores.

This collection of articles can also be found on the journal's homepage at https://www.springer.com/journal/11240/ updates.

\section{References}

Bett B, Gollasch S, Moore A, James W, Armstrong J, Walsh T, Harding R, Higgins TJV (2017) Transgenic cowpeas (Vigna unguiculata L. Walp) expressing Bacillus thuringiensis Vip3Ba protein are protected against the Maruca pod borer (Maruca vitrata). Plant Cell Tiss Org Cult 131:335-345. https://doi.org/10.1007/ s11240-017-1287-3

Fehér A, Pasternak TP, Dudits D (2003) Transition of somatic plant cells to an embryogenic state. Plant Cell Tiss Org Cult 74:201228. https://doi.org/10.1023/A:1024033216561

Gupta S, Van Eck J (2016) Modification of plant regeneration medium decreases the time for recovery of Solanum lycopersicum cultivar M82 stable transgenic lines. Plant Cell Tiss Organ Cult 127:417423. https://doi.org/10.1007/s11240-016-1063-9

Huetteman CA, Preece JE (1993) Thidiazuron: a potent cytokinin for woody plant tissue culture. Plant Cell Tiss Org Cult 33:105-119. https://doi.org/10.1007/BF01983223

Jacyn Baker C, Mock NM (1994) An improved method for monitoring cell death in cell suspension and leaf disc assays using evans blue. Plant Cell Tiss Org Cult 39:7-12. https://doi.org/10.1007/ BF00037585

Murthy HN, Lee EJ, Paek KY (2014) Production of secondary metabolites from cell and organ cultures: strategies and approaches for biomass improvement and metabolite accumulation. Plant Cell Tiss Org Cult 118:1-16. https://doi.org/10.1007/ s11240-014-0467-7

Nakano A, Mii M, Hoshino Y (2021) Simultaneous production of triploid and hexaploid plants by endosperm culture with colchicine treatment in diploid Haemanthus albiflos. Plant Cell Tiss Org Cult 144:661-669. https://doi.org/10.1007/s11240-020-01974-4

O'Brien C, Hiti-Bandaralage JCA, Folgado R, Lahmeyer S, Hayward A, Folsom J, Mitter N (2021) First report on cryopreservation of mature shoot tips of two avocado (Persea americana Mill.) rootstocks. Plant Cell Tiss Org Cult 144:103-113. https://doi.org/10. 1007/s11240-020-01861-y

Thom M, Maretzki A, Komor E, Sakai WS (1981) Nutrient uptake and accumulation by sugarcane cell cultures in relation to the growth cycle. Plant Cell Tiss Org Cult 1:3-14. https://doi.org/10.1007/ BF02318898

von Arnold S, Sabala I, Bozhkov P, Dyachok J, Filonova L (2002) Developmental pathways of somatic embryogenesis. Plant Cell Tiss Org Cult 69:233-249. https://doi.org/10.1023/A:1015673200 621

Publisher's Note Springer Nature remains neutral with regard to jurisdictional claims in published maps and institutional affiliations. 